\title{
Okul Yöneticisi ve Öğretmenlerin Koronavirüs (Covid-19) Salgını Sürecinde Yürütülen Uzaktan Eğitime İlişkin Görüşleri
}

\section{Ferhat Han $^{1} \quad$ Nesip Demirbilek ${ }^{2} \quad$ Hasan Demirtaş ${ }^{3}$}

Type/Tür:

Research/Araştırma

Received/Geliş Tarihi:

November 2/ 2 Kasim 2020

Accepted/Kabul Tarihi: May 26/

26 Mayıs 2021

Page numbers/Sayfa No: 1168

1193

Corresponding

Author/İletişimden Sorumlu

Yazar:ferhathan@gmail.com

\section{$\checkmark$ iThenticate}

This paper was checked for plagiarism using iThenticate during the preview process and before publication. / Bu çalışma ön inceleme sürecinde ve yayımlanmadan önce iThenticate yazılımı ile taranmıştır.

Copyright $\subseteq 2017$ by Cumhuriyet University, Faculty of Education. All rights reserved.

\section{Öz}

Bu çalışmanın amacı koronavirüs salgını nedeniyle acil ve zorunlu olarak yürütülen uzaktan eğitimin olumlu ve olumsuz yönlerini tespit etmektir. Bu amaçla okul yöneticileri ve öğretmenlerin uzaktan eğitim sürecine ilişkin görüşleri alınmıştır. Araştırmada nitel araştırma desenlerinden olgu bilim deseni kullanılmıştır. Araştırmanın evrenini 2019-2020 eğitim öğretim y1lı ikinci döneminde Bingöl ilindeki devlet okullarında görev yapan okul yöneticileri ve öğretmenler oluşturmaktadır. Çalışma grubunda farklı eğitim kademelerinde görev yapan 187 gönüllü katılımcı yer almaktadır. Araştırma verileri yarı yapılandırılmış form ile toplanmıştır. Çevrimiçi olarak toplanan araştırma verilerinin betimsel analizi ve içerik analizi birlikte yapılmıştır. Analiz sonrasında uzaktan eğitimin olumsuz yönlerine ilişkin sekiz, olumlu yönlerine ilişkin altı tema oluşturulmuştur. Araştırma sonuçlarına göre, salgın döneminde yürütülen uzaktan eğitime ilişkin en çok tekrarlanan olumsuz görüş, internet erişimine ve teknolojiye bağlı yaşanan sorunlardır. Bu süreçte birçok öğretmen ve öğrenci EBA'ya bağlanmakta güçlük çekmiştir. Birçok öğrenci uzaktan eğitim için gerekli olan teknolojik cihazlara sahip olmadığından uzaktan eğitim alamamaktadır. Uzaktan eğitim sürecinde, eğitimde fırsat eşitsizliği artmıştır. Özellikle uygulama gerektiren dersler verimsiz geçmektedir. Motivasyon kaybı yaşayan öğrencilerin uzaktan eğitim derslerine katılım düzeyi düşüktür. Bununla birlikte, virüs bulaşma riskini azaltarak salgının önlenmesine katkı sağlaması, eğitimin kesintiye uğramaması, eğitim teknolojilerinin kullanılmasının yaygınlaşması, zaman ve mekan açısından esneklik sağlaması vb., etkenler ise zorunlu uzaktan eğitimin olumlu yönleri olarak görülmektedir.

Anahtar Kelimeler: Koronavirüs, zorunlu, acil, uzaktan eğitim, okul yöneticisi, öğretmen.

\section{Suggested APA Citation/Önerilen APA Atıf Biçimi:}

Han F., Demirbilek, N. \& Demirtaş, H. (2021). Okul yöneticisi ve öğretmenlerin koronavirüs (Covid-19) salgını sürecinde yürütülen uzaktan eğitime ilişkin görüşleri. Cumhuriyet International Journal of Education, 10(3), 1168-1193. http://dx.doi.org/10.30703/cije.819946

\footnotetext{
${ }^{1}$ Dr., Kilis Milli Eğitim Müdürlüğü, Kilis/Türkiye Dr., Kilis National Education Directorate, Kilis/Turkey e-mail: ferhathan@gmail.com ORCID ID: orcid.org/ 0000-0001-6556-9685
}

${ }^{2}$ Dr. Ögr. Üyesi, Bingöl Üniversitesi, Genç Meslek Yüksek Okulu, Çocuk Gelişimi Programı, Bingöl/Türkiye Assist Prof. Dr., Bingöl University, Genç Vocational School, Child Development Program, Bingöl/Turkey e-mail: ndemirbilek@bingol.edu.tr ORCID ID: $\underline{\text { orcid.org/0000-0001-5133-7111 }}$ 


\title{
Views of School Administrators and Teachers on Distance Education During the Covid-19 Pandemic
}

\begin{abstract}
This study aims to determine the positive and negative aspects of distance education, which is carried out urgently and necessarily due to the coronavirus pandemic. For this purpose, the views of school administrators and teachers about the distance education process were taken. Phenomenological design, one of the qualitative research designs, was used in the study. The universe of the study consists of school administrators and teachers working in public schools in Bingöl province in the second term of the 2019-2020 academic year. 187 volunteer participants are working at different educational levels in the study group. Research data were collected through a semi-structured form. Descriptive and content analysis of research data collected online were done together. After the analysis, eight themes related to negative aspects and six themes related to positive aspects of distance education were formed. According to the research results, the most repetitive negative opinion regarding distance education conducted during the pandemic period is the problems related to internet access and technology. During this period, many teachers and students had difficulties in connecting to EBA. Many students cannot receive distance education because they do not have the technological devices required for distance education. In the distance education process, inequality of opportunity in education has increased. Especially, the lessons that require practice are inefficient. Participation in distance education lessons is low for students who experience a loss of motivation. However, factors such as contributing to the prevention of the pandemic by reducing the risk of virus transmission, not interrupting education, the widespread use of educational technologies, providing flexibility in terms of time, place, etc. are seen as positive aspects of compulsory distance education.
\end{abstract}

Keywords: Coronavirus, compulsory, emergency, distance education, school administrator, teacher.

\section{Giriş}

Türkiye' de ve dünyada koronavirüs salgınıyla birlikte yeni bir dönem başlamıştır. Hayatımızın birçok alanını derinden etkileyen salgın, örgün eğitimi de önemli ölçüde etkilemiş ve örgün eğitimin aksamasına neden olmuştur. Salgın nedeniyle örgün eğitimde plânlanan birçok yazılı ve uygulamalı sınav gerçekleştirilememiştir. Türkiye'de salgının ilk zamanları olan 2019-2020 bahar döneminde ilkokullar, ortaokullar ve liseler öncelikle kısa süreli olarak tatil edilmiştir. Salgının devam etmesi ve yayılmasıyla birlikte dersler zorunlu olarak uzaktan eğitim yoluyla yürütülmüştür. 2020-2021 eğitim öğretim y1lı ise öncelikle okul öncesi ve ilkokul birinci sınıflarda kısmi zamanlı olarak başlamıştır. Haftada iki gün olmak üzere yürütülen kısmi zamanlı eğitimde ders süreleri onar dakika kısaltılmıştır. Kısmi eğitim uygulaması zamanla ilkokulun tüm kademelerinde, ortaokul ve liselerin ise son sınıflarında olmak üzere genişletilmiştir. Milli Eğitim Bakanlığ1 (MEB) okullara gönderdiği resmi yazıyla, örgün eğitimle yürütülemeyen derslerin örgün eğitim müfredatına uygun olarak uzaktan eğitim yoluyla yürütülmesini istemiştir. Bakanlık tarafından uzaktan eğitimde çevrimiçi canlı dersler için ilk zamanlarda sadece Eğitim Bilişim A ğı (EBA) canlı ders uygulamasının kullanılması istenmiştir. Süreç içerisinde öğrenci yoğunluğuna bağlı olarak EBA'ya giriş, bağlantı kopması gibi problemler yaşanmıştır. EBA altyapısında yaşanan problemler nedeniyle MEB 
çevrimiçi dersler için açık kaynak kodlu diğer güvenilir uzaktan eğitim platformlarının da kullanılabileceği ifade etmiştir (MEB, 2020). Uzaktan eğitim için farklı platformların kullanılabileceğinin ifade edilmesiyle, okul yönetimi ve öğretmenler güvenilir platform bulma arayışına girmiştir. Bu arayış içerisinde birinci yazarın gözlemlerine göre okul yönetimleri ve öğretmenler arasında hangi programın güvenilir, hangisinin güvenilir olmadığına dair tartışmalar yaşanmıştır. Medyada yer alan bir uzaktan eğitim uygulamasının kullanıcılarının bilgilerinin çaldığ1 iddiası (Sözcü, 2020; Haber7, 2020), öğrenci olmayan bazı kötü niyetli internet kullanıcılarının canlı derslere sızarak dersleri sabote etmesi, öğretmenlerin farklı eğitim platformlarına mesafeli yaklaşmasına neden olmuştur.

Uzaktan eğitime acil ve zorunlu geçiş nedeniyle, süreç içerisinde birçok aksaklık yaşanmıştır. Bu aksaklıklar için temel olarak iki neden gösterilebilir. Birinci neden uzaktan eğitim için gerekli olan teknik altyapı ve kapasitenin yetersiz olmasidir (Al Lily, Ismail, Abunasser ve Alqahtani, 2020). İkinci neden ise baz1 gelenekçi öğretmenlerin uzaktan eğitim teknolojilerini kullanmak istememesi ve bu konuda yetersiz olmasıdır (Nenko, Kybalna ve Snisarenko 2020). Keskin ve Özer Kaya'nın (2020) araştırmalarında ayrıca, uzaktan eğitim sürecinde öğretmen ve öğrenciler arasında çeşitli iletişim sorunları yaşanması uzaktan eğitimin olumsuz yönlerinden biri olarak ifade edilmiştir. Salgın döneminde hazırlıksız ve plânsız olarak örgün eğitim müfredatıyla yürütülmeye çalışılan zorunlu uzaktan eğitime ilişkin aksaklıklar, öğrencilerin çevrimiçi dersler için bilgisayar başında uzun süreler geçirmesinin neden olabileceği olumsuz etkilere ilişkin endişeler, siber güvenlik endişeleri, vb. durumlar eğitimin paydaşlarının ve toplumun uzaktan eğitime olumsuz bakmasına neden olmuştur (Han ve Demirbilek, 2020; Karadağ ve Yücel, 2020).

Bununla birlikte salgın sürecinde uzaktan eğitim konusunda birçok kazanım elde edilmiştir. Uzaktan eğitimle yürütülen dersler sayesinde eğitimin tamamen kesintiye uğraması engellenmiştir. Okul yöneticileri, öğretmenler ve öğrenciler uzaktan eğitim teknolojisiyle tanışmıştır. MEB tarafından bu süreçte, uzaktan eğitimin niteliğini artırma konusunda birçok çalışma yapılmıştır. Salgın süresince, EBA üzerinden eşzamanlı (senkron) ve eş zamansız (asenkron) dersler için gerekli donanım ve yazılım altyapısı güçlendirilmiştir. MEB, Türkiye Radyo Televizyon Kurumu (TRT) ile işbirliği yaparak aynı zamanda TRT EBA kanallarından eş zamansız olarak uzaktan eğitim vermiştir. Bu süreçte MEB, TRT işbirliğinde Türkiye'nin farklı bölgelerinden birçok öğretmenin katılımıyla uzaktan eğitim için ders içerikleri üretilmiştir. İlk olarak yazılı materyallerin uzaktaki bireylere mektup yoluyla gönderilmesiyle başlayan uzaktan eğitim uygulamaları (Moore ve Kearsley, 2005), günümüzde bilişim teknolojilerindeki gelişmelerle birlikte gün geçtikçe artmış, içerik bakımından zenginleşmiş ve daha fazla birey tarafından kullanılmıştır (Djalilova, 2020; İşman, 2011; Kaçan ve Gelen, 2020).

Senkron veya asenkron olarak uzaktan eğitim, sistem yaklaşımı içerisinde amaçlı ve plânlı olarak yürütülen uygulamaların bileşiminden oluşmaktadır (Bozkurt, 2020). Senkron eğitimde öğretmen ve öğrenciler dijital ortamlardaki derslere aynı zamanda katılırken, asenkron eğitimde kayıt altına alınan çeşitli ders videoları ve dokümanlara internet erişimi olan her yerden istenilen anlarda ulaşılabilmektedir (Solak, Ütebak ve Yalçın, 2020). Uzaktan eğitim yaşam boyu 
öğrenme felsefesiyle, çeşitli nedenlerle örgün eğitim alamayan bireylerin eğitim ve öğretimini desteklemektedir. Uzaktan eğitimin sunduğu esneklik sayesinde her birey zaman ve mekân sınırı olmadan eğitim öğretim faaliyetlerinden yararlanabilmektedir (Aydemir, 2018; Moore ve Kearsley, 2011; Özyürek, Begde, Yavuz ve Özkan, 2016).

Türkiye' de birçok üniversite yıllardır uzaktan eğitimle öğrencilerine hizmet vermektedir. Bazı üniversiteler ön lisans, lisans ve lisansüstü düzeylerde birçok bölümde tamamen uzaktan eğitimle faaliyetlerini yürütürken; bazı üniversiteler teorik dersleri uzaktan, uygulamalı dersleri örgün eğitimle yürüterek harmanlanmış/blended eğitim programı uygulamaktadır (Cabı ve Ersoy, 2017; Gelen ve Kaçan, 2020). Türkiye' de uzaktan eğitim yürüten kurum ve kuruluşların ve uzaktan eğitimden yararlanan bireylerin sayısı her geçen gün artmakla beraber (Özyürek vd., 2016), üniversite öncesi eğitim kademelerinde uzaktan eğitim koronavirüs salgınıyla birlikte uygulanmaya başlanmıştır.

Salgın öncesi dönemde de kullanılan EBA, salgın süresince MEB'e bağl1 okullarda yoğun olarak kullanılmaya başlanmıştır. MEB bu süreçte EBA'ya olan talebi karşılamak için gerekli olan donanım ve yazılım altyapısı güçlendirme çalışmaları yapmıştır (Özer, 2020). Salgın süresince online dersler için EBA platformunun yanında, Zoom, Microsoft Teams ve Jitsi Meet gibi video konferans programları da kullanılmıştır.

Türkiye Cumhuriyeti Anayasası'nın 42. maddesinde, kimsenin eğitim ve eğitim hakkından yoksun bırakılamayacağı ve eğitim öğretimin devlet okullarında parasız olduğu ifade edilmiştir (Türkiye Cumhuriyeti Anayasası, 1982). MEB özellikle uzaktan eğitim için gerekli teknolojik araçlara ve internet bağlantısına sahip olmayan öğrencilerin eğitim hakkından mahrum kalmaması için her ilde "EBA Destek Noktaları" oluşturmuştur. Ülke genelinde oluşturulan toplam 15113 sabit EBA destek noktasina ek olarak 185 mobil EBA destek noktası interneti ve bilgisayarı olmayan öğrencilere hizmet vermektedir (MEB, 2021).

Alan yazın araştırmaları ve yazarların gözlemlerine göre uzaktan eğitimin birçok olumlu yönü olmasına rağmen bazı olumsuzlukları da vardır. Bu araştırmada zorunlu uzaktan eğitimin olumlu ve olumsuz yönleri, okul yöneticilerinin ve öğretmenlerin süreç içerisinde yaşadığ1 tecrübelere bağlı olarak oluşan görüşlerinden tespit edilmeye çalışılmıştır. Araştırmanın sonunda, zorunlu uzaktan eğitim sürecinde ortaya çıkan aksaklıklar ve olumlu yönler konusunda farkındalık oluşturulmuştur.

\section{Araştırmanın Amacı}

$\mathrm{Bu}$ araştırmanın amacı, koronavirüs salgını süresince zorunlu olarak yürütülen uzaktan eğitime ilişkin okul yöneticisi ve öğretmenlerin görüşlerini belirlemektir.

\section{Yöntem}

Öğretmenlerin ve okul yöneticilerinin zorunlu uzaktan eğitime ilişkin görüşlerinin incelendiği bu araştırmada nitel araştırma desenlerinden olgu bilim (fenomenoloji) deseni kullanılmıştır. Nitel araştırma, "gözlem, görüşme ve doküman analizi gibi nitel veri toplama yöntemlerinin kullanıldığı, algıların ve olayların doğal ortamda gerçekçi ve bütüncül bir biçimde ortaya konmasına yönelik nitel bir sürecin 
izlendiği araştırma" olarak tanımlanabilir (Yıldırım ve Şimşek, 2013, s. 45). Bu araştırma, özü itibariyle fenomenolojik bir araştırmadır. Fenomenoloji, farkında olunan bir olgunun özünde ne olduğunun yanında, o olgunun doğasının ve anlamının ne olduğunu ortaya çıkarmak için yapılan araştırmaları kapsamaktadır (Yıldırım ve Şimşek, 2013). Fenomenoloji, daha çok insanın iç dünyasını ve onların bilinç yapılarını anlamaya çalışan bir araştırma desenidir (Mayring, Gümüş ve Durgun, 2011). Ayrıca olgu bilim, aşina olduğumuz ancak kesinliği konusunda bilgi sahibi olmadığımız olguların, derinlemesine incelenmesi ve zengin söylemlerle yorumlanması fırsatı sağlayan bir araştırma desenidir (Sönmez ve Alacapınar, 2011; Yaman, Mermer ve Mutlugil, 2009).

\section{Çalışma Grubu}

Çalışmanın evreni, Bingöl İl Milli Eğitim Müdürlüğüne bağlı devlet okullarında 2019-2020 eğitim öğretim yılı ikinci döneminde görev yapan okul müdürü, müdür yardımcısı ve öğretmenler oluşturmaktadır. Katılımcılar, seçkisiz olmayan örnekleme yöntemlerinden uygun örnekleme yöntemiyle seçilmiştir. Uygun örnekleme katılımcı olarak hizmet verecek en uygun kişileri seçmeyi ve gerekli örneklem büyüklüğü elde edilene ya da o sırada ulaşılabilir ve erişilebilir olana kadar bu sürece devam etmeyi içerir. Araştırmacılar kolaylıkla ulaşabileceği kişilerden örneklem seçerler (Cohen, Manion ve Morrison, 2007). Çalışma da Bingöl İl Milli Eğitim Müdürlüğüne bağlı okullarda çalışan öğretmen ve okul yöneticilerinden 187 katılımcı gönüllü olarak yer almıştır. Katılımcıların demografik bilgileri Tablo 1'de sunulmuştur:

Tablo 1

Çalışma Grubunda Yer Alan Katılımcıların Demografik Bilgileri

\begin{tabular}{llrr}
\hline Değişkenler & Kategori & $\mathbf{n}$ & $\mathbf{\%}$ \\
\hline \multirow{3}{*}{ Görev } & Öğretmen & 155 & 83,3 \\
& Müdür Yardımcisı & 14 & 7,5 \\
Toplam & Müdür & 18 & 9,1 \\
\hline
\end{tabular}

\section{Veri Toplama Araçları}

Nitel araştırmalarda veri toplama sürecinin ayrıntılı olarak açıklanması araştırmanın geçerliğini sağlamada önemli ölçütlerden biridir (Yıldırım ve Şimşek, 2013). Bu araştırmada veriler, araştırmacılar tarafından hazırlanan yarı yapılandırılmış form aracılığıyla toplanmıştır. Veri toplama aracı Google form üzerinden hazırlanmış, katılımcılara e-posta olarak ulaştırılmıştır. Veri toplama aracında katılımcılara aşağıda yer alan açı uçlu iki soru yöneltilmiştir.

1. Sizce salgın nedeniyle zorunlu olarak yürütülen uzaktan eğitimin olumsuz yönleri nelerdir?

2. Sizce salgın nedeniyle zorunlu olarak yürütülen uzaktan eğitimin olumlu yönleri nelerdir? 


\section{Verilerin Analizi}

Verilerin analizinde, nitel araştırmalarda kullanılan "betimsel ve içerik analizi" yöntemi uygulanmıştır. Betimsel analizde bireylerin görüşlerini dikkat çekici biçimde yansıtmak amacıyla doğrudan alıntılara sık sık yer verilir. İçerik analizinde ise temelde yapilan işlem, birbirine benzeyen verileri belirli kavramlar ve temalar çerçevesinde bir araya getirmek ve bunları okuyucunun anlayabileceği bir biçimde düzenleyerek yorumlamaktır. Nitel araştırmalarda veriler, (1) verilerin kodlanması, (2) temaların bulunması, (3) kodların ve temaların düzenlenmesi ve (4) bulguların tanımlanması ve yorumlanması şeklinde dört aşamada analiz edilmektedir (Yıldırım ve Şimşek, 2013). Bununla birlikte bu aşamalar birbirinden bağımsız ve birbirini takip eden değil, iç içe geçmiş ve çoğu kez bir arada yürütülen süreçlerdir. Nitel veri analizi ve bulguların yazılma süreçleri birbirleri ile bağımlı olgular olarak düşünülmelidir (Silverman ve Marvasti, 2008).

Araştırma verilerine ilişkin her bir forma katılımcılar için bir sıra numarası verilmiştir. Sıralaması sabit kalacak şekilde katılımcılar görevlerine göre kodlanmıştır. Örneğin, 138. sıradaki katılımcının görevi öğretmen ise Ö138 şeklinde kodlanmıştır. Okul müdürleri M1, M2...müdür yardımcıları, MY1, MY2 ..., öğretmenler ise Ö1, Ö2 ... şeklinde kodlanmıştır. Online formda yer alan sorulara verilen yanıtlar araştırmacılar tarafından analiz edilirken öncelikle birkaç defa okunmuştur. Okumalar sırasında aynı zamanda kodlara, temalara ve alt temalara ilişkin bir liste hazırlanmıştır. Kodlama, veri toplama sürecinde elde edilen verilerin küçük bilgi kategorileri altında birleştirmeyi, gereksiz ve fazla olan bilgileri ayıklayarak verilerle oluşmuş her kod için bir etiket verme olarak açıklanabilir. Tema ise benzerlikleri olan birkaç kodun bir araya gelerek oluşturduğu geniş bilgi birimi olarak tanımlanabilir (Creswell, 2016). Bu doğrultuda araştırmacılar, verilerden kodları ve birbirine benzerlikleri olan kodları da bir araya getirerek temalar oluşturmuşlardır (Yıldırım ve Şimşek, 2013). Nitel araştırmalarda içerik analizleri sonucunda elde edilen verilerin yorumlanmasında genellikle frekans ve yüzde kullanılır (Büyüköztürk, Çakmak, Akgün, Karadeniz ve Demirel, 2010: 273). Bu araştırmada araştırmacılar tarafından ortaya çıkarılan kodlar tekrarlanma sıklığına göre sıralanmış ve bu sıklık frekans değerleri olarak gösterilmiştir.

Elde edilen verilerin kodlamaları, araştırmacılar ve eğitim yönetimi alanında görev yapan bir akademisyen tarafından yapılmıştır. Tema oluşturma işleminin birden fazla kişi tarafından yapılması araştırmanın güvenirliğinin artmasına olanak sağlamıştır (Yıldırım ve Şimşek, 2013). Kodlamalara ait karşılaştırmalar sonucunda, bu araştırmanın güvenirliği (Güvenirlik = Görüş birliği/Görüş birliği + Görüş ayrılığ 1 x 100) ile hesaplanmıştır (Miles ve Huberman, 1994; Akt. Şenel ve Aslan, 2014). Araştırma için yapılmış olan hesaplamalar sonucunda \% 84 oranında bir uzlaşma olduğu sonucuna ulaşılmıştır.

\section{Araştırmacıların Rolü}

Nitel araştırmalarda görüşmelerle birlikte gözlemler de temel veri kaynağıdır. Gözleme dayalı veriler görüşmede ikincil kişilerden elde edilen bilgilerden ziyade, ilgi alanı ile ilgili birinci elden bir karşılaştırma yapılmasını mümkün kılar (Merriam, 2013). Olgu bilim deseninde, araştırmacıların gözlemleri ve deneyimleri 
olgunun özünün doğru bir şekilde yansıtılmasına katkı sağlar (Onat Kocabıyık, 2016). Bu araştırmanın yürütücülerinden olan ilk araştırmacı bir devlet okulunda bilişim teknolojileri rehber öğretmeni olarak görev yapmaktadır. İlgili yazar korona virüs salgını süresince ayrıca okul EBA temsilcisi olarak görev yapmaktadır. Araştırmanın giriş, tartışma ve sonuç kısmında yer alan bazı yorum ve öneriler yazarın süreç içerisindeki gözlem ve deneyimlerine dayanmaktadır. Araştırma da ikinci yazar verilerin toplanmasını sağlamıştır. Araştırma süresince birinci ve ikinci yazar kuramsal çerçevenin oluşturulması, yöntem bölümünün yazılması, verilerin analiz edilmesi, bulgular, sonuç, tartışma ve öneriler bölümlerinin geliştirilmesinden sorumlu olmuştur. Üçüncü yazar verilerin analizinde destek olmuş, ayrıca araştırma süresince öneriler sunup, düzeltmeler yaparak araştırmanın niteliğine katkı sağlamıştır.

\section{Birinci Alt Probleme İlişkin Bulgular}

\section{Bulgular}

Uzaktan eğitimin olumsuz yönlerine ilişkin bulgular "Sizce salgın nedeniyle zorunlu olarak yürütülen uzaktan eğitimin olumsuz yönleri nelerdir?" sorusu aracıllı̆̆1yla elde edilmiştir. Uzaktan eğitimin olumsuz yönlerine ilişkin katılımcı görüşleri Tablo 2 ' de verilmiştir.

Tablo 2

Uzaktan Eğitimin Olumsuz Yönlerine İlişkin Temalar ve Kodlar

\begin{tabular}{|c|c|c|}
\hline Temalar & Kodlar & $f$ \\
\hline \multirow{19}{*}{$\begin{array}{l}\text { İnternet erişimi, } \\
\text { teknolojik araçlar ve } \\
\text { teknolojiye ilişkin } \\
\text { olumsuzluklar }\end{array}$} & İnternet erişiminde eksiklikler olması & 53 \\
\hline & $\begin{array}{l}\text { Öğrencilerde teknolojik araçların ve materyallerin (bilgisayar, } \\
\text { tablet, telefon) olmaması }\end{array}$ & 39 \\
\hline & İnternet altyapı eksikliği & 26 \\
\hline & EBA'nın yoğunluktan dolayı yetersiz olması ve teknik aksaklıklar & 16 \\
\hline & Öğrencilerin stabil ve sınırsız internet bağlantısına sahip olamaması & 12 \\
\hline & Öğrencilerin yaşadığı yerlerde şebeke sorunu olması & 9 \\
\hline & Mevcut internet kalitesinin iyi olmaması & 7 \\
\hline & Velilerin teknolojiyi kullanma konusunda yetersiz olması & 7 \\
\hline & $\begin{array}{l}\text { Öğretmenlerde teknolojik araçların ve materyallerin (bilgisayar, } \\
\text { tablet, telefon) olmaması }\end{array}$ & 6 \\
\hline & EBA canlı ders uygulamasına bağlanma sorunu & 6 \\
\hline & EBA'da bağlantı kopukluğu & 6 \\
\hline & Öğrencilerde teknolojik bilgi yetersizliğinin olması & 5 \\
\hline & $\begin{array}{l}\text { Öğrencilerde teknolojik araçların ve materyallerin (bilgisayar, } \\
\text { tablet, telefon) yeteri kadar olmaması }\end{array}$ & 4 \\
\hline & Öğretmenlerde teknolojik bilgi yetersizliğinin olması & 4 \\
\hline & Öğretmenlerin dijital ortama ayak uyduramaması & 3 \\
\hline & Sistemden öğrencilerin sürekli atılması & 3 \\
\hline & Diğer okuyan aile bireyleri ile derslerin çakışması & 2 \\
\hline & Teknolojik bir yoğunluğun olması & 1 \\
\hline & EBA'nın çökmesi & 1 \\
\hline Toplam & & 210 \\
\hline & Öğrencilerin derslere katılamaması & 18 \\
\hline $\begin{array}{l}\text { Derslerin işlenmesine } \\
\text { ilişkin olumsuzluklar }\end{array}$ & $\begin{array}{l}\text { Uygulamalı etkinlikleri (PDR, görsel sanatlar, beden eğitimi, resim, } \\
\text { müzik, beden, bilişim, görsel sanatlar, meslek } \\
\text { uygulamaları)yapmanın zor olması }\end{array}$ & 10 \\
\hline
\end{tabular}


Ders anlatırken göz ve fiziksel temasın olmaması 9

Derslerin verimsiz geçmesi 9

Derse katılan öğrencilerin az olması $\quad 6$

Öğrencilerin uzaktan eğitime yeteri kadar katılamaması 6

Yüz yüze eğitim süreci kadar etkili ve işlevsel olamaması 5

Derslerde, öğrencilerden sağlıklı dönüt alınamaması 5

Öğrencinin ev ortamının derslere uygun olmaması 4

Ailelerin canlı ders sirasında müdahale etmesi 4

Çevrimiçi ders saatlerinin kısa ve yetersiz olması 4

Öğrencilerin derslerden faydalanmaması ve geri kalması 4

Eğitim kalitesinin düşmesi 2

Derslerde devam zorunluluğunun olmaması 2

İstenilen düzeyde dersin islenememesi 1

Ders bütünlüğünün olmaması 1

Öğretmenin ev ortamının derslere uygun olmaması 1

Derslerde konu anlatımında yetersiz kalınması 1

Konuyu pekiştirecek uygulamalı etkinlik yapamıor olunması 1

Toplam

Öğrencilerin motivasyon eksikliği 20

Her öğrenciye ulaşamamak ve kavuşamamak 17

Öğrenciler ile iletişim eksikliği 14 Motivasyon ve
iletişime ilişkin
olumsuzluklar

Toplam

Öğrenciler ile birebir iletişimin olmaması 4

Öğrenciler ile etkileşim eksikliği 3

Çocukların duygusuna hitap edememesi 2

Taşımalı okullarda öğrenci ve velilerle iletişim 2

Öğrencilerin ekran karşısında sıkılmaları 2

Öğrencilerin hazır bulunuşunun yetersiz olması 1

Öğretmenlere ulaşamama 1

Öğretmenlerin motivasyon eksikliği 1

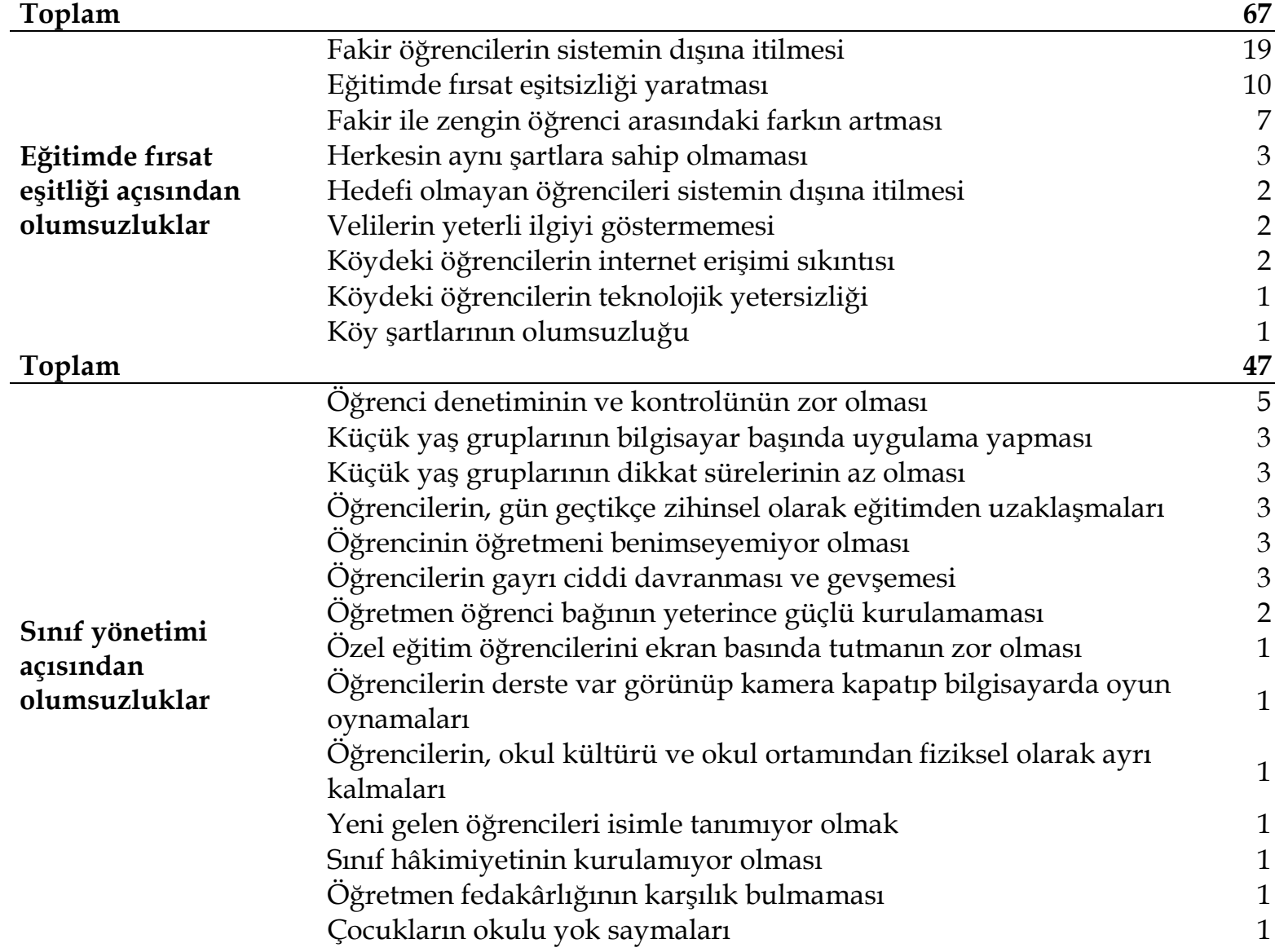


Zorunlu ve plânsız olması

Okulların yeterli donanıma sahip olmaması

Birinci sınıfların ve okuma yazmaya yeni geçen öğrencilerin uzaktan eğitime hazır olmaması

Bakanlıkça yeterli alt yapının sağlanamamış olması 2

Zorunlu olmasindan

Okullarımızın bu alanda hiçbir deneyiminin bulunmaması

Uzaktan eğitimin niteliğine ilişkin sorunların öğretmen, öğrenci ve

Uzaktan eğitim için ders kitaplarının yetersiz olması

Sürekli değişen uygulamalar

Ders içeriklerinin uzaktan eğitime uygun olmaması

Öğrencilerim, duyuşsal ve bilişsel olarak uzaktan eğitime hazır

olmaması

Bakanlığın bu alanda hiçbir deneyiminin bulunmaması 1

Toplam

Öğrencilerde teknoloji bağımlılığı yaratması

Öğrencilerin asosyalleşmesine sebep olması

Yeni sorunlara neden olmasi

Sürekli bilgisayar karşısında oturmanın verdiği (oturuş-omurga

bozuklukları) fiziksel rahatsızlık

Salgın nedeniyle insanlarda oluşan psikolojik yorgunluk

Ekran bağımlısı yapması

Toplam

Olumsuz yönünün

olmadığını ifade eden Uzaktan yürütülen eğitimin olumsuz yönünün olmaması katılımcilar

Tablo 2 incelendiğinde okul yöneticilerinin ve öğretmenlerin zorunlu uzaktan eğitimin olumsuz yönlerine ilişkin görüşleri çerçevesinde oluşturulan temaların frekans bakımından sırasıyla; internet erişimi, teknolojik araçlar ve teknolojiye ilişkin olumsuzluklar, derslerin işlenmesine ilişkin olumsuzluklar, motivasyon ve iletişime ilişkin olumsuzluklar, eğitimde fırsat eşitliği açısından olumsuzluklar, sınıf yönetimi açısından olumsuzluklar, zorunlu ve plânsız olmasindan kaynaklı olumsuzluklar, yeni sorunlara neden olması ve olumsuz yönünün olmadığını ifade eden katılımcılar olmak üzere toplamda sekiz tema olarak değerlendirilmiştir.

İnternet erişimi, teknolojik araçlar ve teknolojiye ilişkin olumsuzluklar temasında katılımcılar en çok, öğrencilerin internet ya da teknolojik araçlarının olmamasından kaynaklı eğitimlerine devam edemediklerini ifade etmişlerdir. $\mathrm{Bu}$ tema altında katılımcılar frekans değerlerine göre çoktan aza doğru sıralamada; internet erişiminde eksiklikler olması, öğrencilerde teknolojik araçların ve materyallerin (bilgisayar, tablet, telefon) olmaması, internet altyapı eksikliği, EBA'nın yoğunluktan dolayı yetersiz olması ve teknik aksaklıklar, öğrencilerin stabil ve sınırsız internet bağlantısına sahip olamaması, öğrencilerin yaşadığı yerlerde şebeke sorunu olması, mevcut internet kalitesinin iyi olmaması, velilerin teknolojiyi kullanma konusunda yetersiz olması, öğretmenlerin teknolojik araç ve materyallere sahip (bilgisayar, tablet, telefon) olmamas1, EBA canlı ders uygulamasına bağlanma sorunu, EBA'da bağlantı kopukluğu, öğrencilerin teknolojik bilgi açısından yetersiz olması, öğrencilerde teknolojik araçların ve materyallerin (bilgisayar, tablet, telefon) yeteri kadar olmaması, öğretmenlerde teknolojik bilgi yetersizliğinin olması, öğretmenlerin dijital ortama ayak 
uyduramaması, sistemden öğrencilerin sürekli atılması, diğer okuyan aile bireyleri ile derslerin çakışması, teknolojik bir yoğunluğun olması ve EBA'nın çökmesi şeklinde olumsuz görüş ifade etmişlerdir. İnternet erişimi, teknolojik araçlar ve teknolojiye ilişkin olumsuzluklar temasında bazı katılımcıların görüşleri şöyledir.

Internet erişiminde sıkıntı var. Birçok öğrencinin bilgisayar veya tableti hatta telefonları yok. Sinırsız internetleri yok. Birçok veli EBA'yı kullanmayı bilmiyor. En az 10dk. ses geliyor mu, görüntü var mı vs. uğraşıp duruyoruz. Sistem yoğun, giremiyoruz vs. sorun çok (Ö157).

Öğrencilerin evde kardeşleri ile dersleri çakıştığından dolayı EBA'ya başka bir girme imkânın olmadığından derse katılmaması (Ö127).

Türkiye'de öğrencilerin yarısından fazlasının internet erişimi ve bilgisayarının olmaması (Ö90).

Derslerin işlenmesine ilişkin olumsuzluklar temasında katılımcılar en çok, öğrencilerin uzaktan eğitim derslerine katılamadığını, derslerin verimsiz ve etkisiz yürütüldüğünü ifade etmişlerdir. Bu tema altında katılımcılar frekans değerlerine göre çoktan aza doğru sıralamada; öğrencilerin derslere katılamaması, uygulamalı etkinlikleri (PDR, görsel sanatlar, beden eğitimi, resim, müzik, beden, bilişim, laboratuvar, görsel sanatlar, meslek uygulamaları) yapmanın zor olması, ders anlatırken göz ve fiziksel temasın olmaması, derslerin verimsiz geçmesi, derse katılan öğrencilerin az olması, öğrencilerin uzaktan eğitime yeteri kadar katılamaması, yüz yüze eğitim süreci kadar etkili ve işlevsel olamaması, derslerde öğrencilerden sağlıklı dönüt alınamaması, öğrencinin ev ortamının derslere uygun olmaması, ailelerin canlı ders sırasında müdahale etmesi, çevrimiçi ders saatlerinin kısa ve yetersiz olması, öğrencilerin derslerden faydalanmaması ve geri kalması, eğitim kalitesinin düşmesi, derslerde devam zorunluluğunun olmaması, istenilen düzeyde dersin işlenememesi, ders bütünlüğünün olmaması, öğretmenin ev ortamının derslere uygun olmaması, derslerde konu anlatımında yetersiz kalınması ve konuyu pekiştirecek uygulamalı etkinlik yapamıyor olunması şeklinde olumsuz görüş ifade etmişlerdir. Derslerin işlenmesine ilişkin olumsuzluklar temasında katılımcılardan bazılarının görüşleri şöyledir.

Bir beden eğitimi öğretmeniyim. Uygulamalı eğitimleri ZOOM üzerinden veremiyorum.

İletişimde çok önemli olan jest mimik ve göz teması vb. iletişim unsurlarının yetersiz olması (Ö117).

Bazı öğrencilerin ev ortamında çeşitli nedenlerle derse tam odaklanamaması (Ö140).

Öğrenci katılımı konusunda büyük eksiklikler yaşanıyor. Süreç tamamen velinin bilinç düzeyine göre olumlu ya da olumsuz olarak çocuklara yanslyor. Öğretmenlerin canlı dersler konusundaki çaba ve fedakârlıkları öğrenci katılımı konusunda karşılık bulmuyor. Öğrenciler, okul kültürü ve okul ortamından fiziksel olarak ayrı kalmalarının yanı sıra zihinsel olarak da kopmuş durumdalar (M49).

Motivasyona ve iletişime ilişkin olumsuzluklar temasında, katılımcılar en çok iletişim ve motivasyon açısından uzaktan eğitimden memnun olmadıklarını ifade etmişlerdir. Bu tema altında katılımcılar frekans değerlerine göre çoktan aza doğru sıralamada; öğrencilerin motivasyon eksikliği, her öğrenciye ulaşamamak ve kavuşamamak, öğrenciler ile iletişim eksikliği, öğrenciler ile birebir iletişimin olmaması, öğrenciler ile etkileşim eksikliği, çocukların duygusuna hitap edememesi, taşımalı okullarda öğrenci ve velilerle iletişim, öğrencilerin ekran karşısında sıkılmaları, öğrencilerin hazır bulunuşunun yetersiz olması, öğretmenlere ulaşamama ve öğretmenlerin motivasyon eksikliği şeklinde olumsuz görüş ifade etmişlerdir. Motivasyona ve iletişime ilişkin olumsuzluklar temasında katılımcılardan bazılarının görüşleri şöyledir. 
Öncelikle iletişimde göz temasına inanan biriyim. Anlattığım şeyi öğrencimin anlayıp anlamadığın bakışından sezebilirim. Ama uzaktan bu mümkün değil. Öğrenci ile yüz yüze iletişim, öğrencinin öğretmeni benimsemesi açısından da kritik bir önemde bence. Ama uzaktan bu da mümkün değil (Ö16).

Öğrencilerde motivasyonun düşük olması, yüz yüze eğitimin yerini hiç bir şekilde dolduramaması, erişim ve iletişimde yaşanan sıkıntılar şeklinde ifade edebilirim (MY87).

Eğitimde fırsat eşitliği açısından olumsuzluklar temasında, katılımcılar en çok, uzaktan eğitim ile birlikte eşitsizliğin daha da büyüdüğünü ifade etmişlerdir. Bu tema altında katılımcılar frekans değerlerine göre çoktan aza doğru sıralamada; fakir öğrencilerin sistemin dışına itilmesi, eğitimde fırsat eşitsizliği yaratması, fakir ile zengin öğrenci arasındaki farkın artması, herkesin aynı şartlara sahip olmaması, hedefi olmayan öğrencileri sistemin dışına itilmesi, velilerin yeterli ilgiyi göstermemesi, köydeki öğrencilerin internet erişimi sıkıntısı, köydeki öğrencilerin teknolojik yetersizliği ve köy şartlarının olumsuzluğu şeklinde olumsuz görüş ifade etmişlerdir. Eğitimde fırsat eşitliği açısından olumsuzluklar temasında katılımcılardan bazılarının görüşleri şöyledir.

Ders saatleri çok yetersiz, konuları hakkıyla işleyemiyoruz. Verimli ders yapabilmek için o sınıfın havasinı teneffüs edemiyoruz. Interneti olmayan öğrenciler çok mağdur durumda. Ĕ̆itimde firsat eşitliğinden faydalanamıyorlar (Ö119).

Interneti olmayan alamayan ve maddi durumu olmayanlara büyük bir haksıllk olmaktadır. Devlet 3-5 GB değil bütün operatörlere EBA vb. sitelere girişe ücretsiz şartı koşmalıdır (Ö138).

Özellikle ekonomik olarak yetersiz olan ailede yaşayan öğrenciler gerek internet gerekse tablet bilgisayar $v b$. araçlar konusunda eksik kaldikları için süreçten faydalanamamaktadır... Uzaktan tüm öğrencilere ulaşılamamakta... (M45).

Sınıf yönetimi açısından olumsuzluklar temasında, katılımcılar en çok sınıf hakimiyetinin kurulamadığına ilişkin görüş ifade etmişlerdir. Bu tema altında katılımcılar frekans değerlerine göre çoktan aza doğru sıralamada; öğrenci denetiminin ve kontrolünün zor olması, küçük yaş gruplarının bilgisayar başında uygulama yapması, küçük yaş gruplarının dikkat sürelerinin az olması, gün geçtikçe öğrencilerin zihinsel olarak eğitimden uzaklaşmaları, öğrencinin öğretmeni benimseyemiyor olması, öğrencilerin gayrı ciddi davranması ve gevşemesi, öğretmen öğrenci bağının yeterince güçlü kurulamaması, özel eğitim öğrencilerini ekran basında tutmanın zor olması, öğrencilerin derste var görünüp kamera kapatıp bilgisayarda oyun oynamaları, öğrencilerin, okul kültürü ve okul ortamından fiziksel olarak ayrı kalmaları, yeni gelen öğrencileri isimle tanımıyor olmak, sınıf hâkimiyetinin kurulamıyor olması, öğretmen fedakârlığının karşılık bulmaması ve çocukların okulu yok saymaları şeklinde olumsuz görüş beyan etmişlerdir. Sınıf yönetimi açısından olumsuzluklar temasında bazı katılımcıların görüşleri şöyledir.

Ailelerin eğitimin içine çok fazla girmesi canlı ders sırasında annelerle muhatap olmak zorunda kalıyoruz (Ö29).

Olumsuz rutinleri geçeyim birçok kişi yazar zaten. Zoom için WhatsApp gruplarında link paylaştığımızda öğrencilerimin linki etrafa dağıtması ve canlı ders esnasında koca koca adamların bir sürü değişik IP adresi ile derse girmeye çalışması, sonradan saçma sapan sesler gelince hemen sesini kısmam veya çıkarmam (belki ailesinin telefonundan giriyordur diye düşünerek dersten çıkartamamam kameralarn isteğe bağlı açılması. WhatsApp gruplar kurduğumuzda kendime yeni telefon almak zorumda kaldım. 1700 ögrencide telefonumun olmasını istemedim sinıfim olsa tabi ki olabilirdi. Tüm okul olduğu için. Buna rağmen gecenin 12'sinde görüntülü arandım kayıtlarımda mevcut. Daha tedbirli nasıl olunur, daha să̆lıkl nasıl devam edilir bilmiyorum ama en azından bunlar bilirseniz 
bizim neler yaşadığımızı da birazcı belki anlar bunlarla ilgilide önlem alabilirsiniz

(Ö179).

Uzaktan eğitimin zorunlu olmasından kaynaklı olumsuzluklar temasında, katılımcılar en çok, uzaktan eğitime bir anda karar verilip uygulamaya geçildiği için aksaklıkların yaşandığına ilişin görüş ifade etmişlerdir. Bu tema altında katılımcılar frekans değerlerine göre çoktan aza doğru sıralamada; zorunlu ve plânsız olması, okulların yeterli donanıma sahip olmaması, birinci sınıfların ve okuma yazmaya yeni geçen öğrencilerin uzaktan eğitime hazır olmaması, bakanlıkça yeterli alt yapının sağlanamamış olması, okullarımızın bu alanda hiçbir deneyiminin bulunmaması, uzaktan eğitimin niteliğine ilişkin sorunların öğretmen, öğrenci ve velilerin uzaktan eğitime bakışını olumsuz etkilemesi, uzaktan eğitim için ders kitaplarının yetersiz olması, sürekli değişen uygulamalar, ders içeriklerinin uzaktan eğitime uygun olmaması, öğrencilerim, duyuşsal ve bilişsel olarak uzaktan eğitime hazır olmaması ve bakanlığın bu alanda hiçbir deneyiminin bulunmaması şeklinde olumsuz görüş ifade etmişlerdir.

Uzaktan eğitim verilebilmesi için teknolojinin yanında öğrencilere buna uygun kaynak ve materyal temin edilmesi gerekiyor. Ders kitaplarn normalde yetersiz, uzaktan eğitim verebilmek için ise sıfır düzeyde... (Ö8).

Okulumuzun interneti olmasina rağmen alt yapıdan kaynaklı interneti yok bir EBA sinifi oluşturamıyoruz. Bu sebepten öğrencilerden kaynakl uzaktan eğitim de ne yazık ki katılım yok denecek kadar az (Ö97).

Yeni sorunlara neden olması temasında katılımcılar en çok, uzaktan eğitim uygulamasının, yeni sorunlara yol açtığını ifade etmişlerdir. Bu tema altında katılımcılar frekans değerlerine göre çoktan aza doğru sıralamada; öğrencilerde teknoloji bağımlılığı yapması, öğrencilerin asosyalleşmesine sebep olması, sürekli bilgisayar karşısında oturmanın verdiği (oturuş-omurga bozuklukları) fiziksel rahatsızlık, salgın nedeniyle insanlarda oluşan psikolojik yorgunluk ve ekran bağımlısı yapması şeklinde olumsuz görüş beyan etmişlerdir. Bununla birlikte bazı katılımcılar, acil ve zorunlu olarak yürütülen uzaktan eğitimin olumsuz yönünün olmadığını ifade etmişlerdir.

Ekranlara mahkûmiyet ve maruz kalma, psikolojik-pedagojik zararlar, oturuş-omurga bozuklukları, ciddi mali külfetler(bilgisayarm patladı, yenisini almak zorunda kaldım, sinirsız internet paketi almak zorunda kaldım, evimi ve özel teknik donanımımı, okula ve ögrrencilere tahsis etmek zorunda kaldım. Şekerim ve tansiyonum firladı(Ö165).

Sosyal bir varlık olduğumuz için bu durum hem öğretmenleri hem de öğrencileri olumsuz etkiliyor. Çocuklarm bir arada olması, oyuna sikça başvurmalarn çocuğu gerek eğitim gerekse öğretim açısından geliştiren çok büyük bir etkendir. Bu salgin özellikle çocukların motivasyonunu büyük ölçüde düşürdü (Ö141).

\section{İkinci Alt Probleme İlişkin Bulgular}

Uzaktan eğitimin olumlu yönlerine ilişkin bulgular "Sizce salgın nedeniyle zorunlu olarak yürütülen uzaktan eğitimin olumlu yönleri nelerdir?" sorusu aracılığılyla elde edilmiştir. Uzaktan eğitimin olumlu yönlerine ilişkin katılımcı görüşleri Tablo 3’de verilmiştir. 
Tablo 3

Uzaktan Eğitimin Olumlu Yönlerine İlişkin Temalar ve Kodlar

\begin{tabular}{|c|c|c|}
\hline Temalar & Kodlar & $f$ \\
\hline \multirow{26}{*}{$\begin{array}{l}\text { Teknoloji ile eğitimin iç } \\
\text { içe olmasından kaynaklı } \\
\text { olumlu yönler }\end{array}$} & Teknoloji kullanımının yaygınlaşması & 14 \\
\hline & Öğretmenlerin teknolojik bilgisinin artması & 14 \\
\hline & Teknolojik gelişim & 12 \\
\hline & Teknoloji bilgisinin artması & 12 \\
\hline & Eğitim ile teknolojinin daha etkin ve verimli bir şekilde & \\
\hline & kullanılması & \\
\hline & Dijital ve teknoloji çă̆ına ayak uydurulması & 9 \\
\hline & Öğretmenlerin teknoloji kullanımının artması & 8 \\
\hline & $\begin{array}{l}\text { Öğrencilerin küçük yaşta uzaktan eğitim teknolojisini tanımış } \\
\text { olmaları }\end{array}$ & 7 \\
\hline & İdarecilerin teknoloji bilgisinin artması & 6 \\
\hline & Teknolojinin eğitim için faydalarının anlaşılması & 6 \\
\hline & Eğitimin farklı ve alternatif araçlarla yapılması & 5 \\
\hline & Bazı öğrencilerde öz denetimin artması & 5 \\
\hline & Velilerin teknoloji bilgisinin artması & 5 \\
\hline & Öğrencilerin teknoloji bilgisinin artması & 5 \\
\hline & Eğitim ile teknolojinin iç içe olması & 5 \\
\hline & Eğitsel dijital içeriklerin çoğalması ve paylaşılması & 5 \\
\hline & $\begin{array}{l}\text { Bazı öğrencilerin bireysel çalışma (çalışmalarını kendi düzenleme, } \\
\text { plân yapma vs.) alışkanlığı kazanması }\end{array}$ & 4 \\
\hline & Öğretmenlerin uzaktan eğitim teknolojisini tanımış olmaları & 4 \\
\hline & Öğrencilerin kendi başına öğrenmeyi öğrenmesi & 3 \\
\hline & Derslere katılan öğrenciler de okul bilinci gelişmesi & 3 \\
\hline & EBA'nın hiç yoktan iyi olması & 3 \\
\hline & Öğretmenlerin uzaktan eğitimi öğrenmesi & 2 \\
\hline & Salgın sonrası süreçte tekrara imkân sağlayacak olması & 2 \\
\hline & Öğrencilerin eksik yönlerinin görülmesi & 1 \\
\hline & Velilerin uzaktan eğitimi öğrenmesi & 1 \\
\hline Toplam & & 150 \\
\hline \multirow{15}{*}{$\begin{array}{l}\text { Sağlık açısından olumlu } \\
\text { yönler }\end{array}$} & Salgının (virüs) yayılımını önlemesi & 21 \\
\hline & Salgının artmasını ve bulaş riskini azaltması & 19 \\
\hline & $\begin{array}{l}\text { Uzaktan eğitimin sağlık açısından risk taşımaması ve sağlıklı } \\
\text { olması }\end{array}$ & 13 \\
\hline & Öğrencileri salgına yakalanmasını engellemesi & 9 \\
\hline & Hastalıktan koruması ve uzak tutması & 9 \\
\hline & Öğrencilerin salgından dolayı güvende olması & 8 \\
\hline & Yakın temasın olmaması ve temaslı ortamdan uzak olması & 5 \\
\hline & Hastalık yapan virüslerden izole bir yaşam sürmemizi sağlaması & 5 \\
\hline & Sağlık açısından kaygının azalması & 5 \\
\hline & Korkusuz ve kaygısız ders işleniyor olması & 4 \\
\hline & Daha steril ve hijyenik ortamda ders işlenmesi & 3 \\
\hline & Çocukların velilerin yanında olması & 2 \\
\hline & Okulların eve sığdırılması & 2 \\
\hline & Okul gibi kalabalık ortamlardan uzak tutması & 1 \\
\hline & Vaka sayısının kontrol altına alınabilmesi & 1 \\
\hline Toplam & & 107 \\
\hline \multirow{4}{*}{$\begin{array}{l}\text { Eğitim, öğretmenler ve } \\
\text { dersler açısından olumlu } \\
\text { yönler }\end{array}$} & $\begin{array}{l}\text { Hiç eğitim almamasındansa kısmen de olsa uzaktan eğitim ile } \\
\text { belirli kazanımların elde edilmesi }\end{array}$ & 6 \\
\hline & Şartlar ne olursa olsun eğitime devam edilebilmesi & 5 \\
\hline & Öğretmenlerin az da olsa öğrencilerine ulaşabilmesi & 5 \\
\hline & Öğrencilerin derslerden geri kalmaması ve tamamen kopmaması & 4 \\
\hline
\end{tabular}


Öğretmenlerin değerinin fark edilmesi 3

Sözel anlatımlı ve teorik derslerde verimli olması 3

Okulun değerinin fark edilmesi 3

Ailelerin sürece daha aktif katılması 2

Yüz yüze eğitimin değerinin fark edilmesi 2

Verilen ödevlerin, takip edilmesinin daha kolay olması 2

Öğrencilerin velilerine daha fazla sorumluluk yüklemesi 2

Derslerin kolaylaşması 1

Kalabalık siniflar sorununu ortadan kaldırması. 1

Veli ilgisinin artması 1

Uzun vadede eğitim maliyetlerini düşürecek olması. 1

Online eğitimle ilgili ciddi bir bilgi birikimi ve tecrübe oluşması 1

Toplam

Evden daha rahat çalışabilmesi 6

Her zaman eğitim verilebilmesi 4

Her yerde eğitim verilebilmesi $\quad 4$

Okula gidişte zaman kaybı olmaması 3

Çok erken saatlerde uyanıp yollara düşmenin olmaması 3

Zaman ve mekân $\quad$ Esnek çalışmaya izin vermesi $\quad 2$

açısından olumlu yönler $\quad$ Zaman tasarrufu sağlaması ve kazandırması 2

Daha kısa zamanda daha kalabalık gruplara eğitim verilebilmesi $\quad 2$

Öğrencilerin kendilerini daha özgür hissetmesi 1

Öğretmenlerin aileleri daha fazla vakit geçirmesi 1

Saat kısıtlamasının olmaması 1 $\begin{array}{ll}\text { Okula gelmede problem yaşayan öğrenciler için iyi bir fırsat } & 1 \\ \text { olması } & \end{array}$

Toplam

\begin{tabular}{llr} 
Toplam & & 30 \\
\hline Diğer olumlu yönler & Trafik kazalarının azalması & 1 \\
Toplam & Okul idaresinin çok özverili çalışmaları & 1 \\
\hline $\begin{array}{l}\text { Olumlu yönünün } \\
\text { olmadığını ifade eden } \\
\text { katılımcılar }\end{array}$ & Herhangi bir olumlu yönü görmedim & $\mathbf{2}$ \\
\hline
\end{tabular}

Tablo 3 incelendiğinde, katılımcıların zorunlu uzaktan eğitimin olumlu yönlerine ilişkin görüşleri çerçevesinde oluşturulan temalar frekans bakımından sırasıyla; teknoloji ile eğitimin iç içe olmasından kaynaklı olumlu yönler, sağlık açısından olumlu yönler, eğitim, öğretmenler ve dersler açısından olumlu yönler, olumlu yönünün olmadığını ifade eden katılımcılar, zaman ve mekân açısından olumlu yönler ve diğer olumlu yönler olmak üzere toplamda altı tema olarak değerlendirilmiştir.

Teknoloji ile eğitimin iç içe olmasından kaynaklı olumlu yönler temasında, katılımcıları en çok eğitimin, teknoloji ile daha etkin ve verimli kullanıldı̆̆ını ifade etmişlerdir. Bu tema altında katılımcllar frekans değerlerine göre çoktan aza doğru sıralamada; teknoloji kullanımının yaygınlaşması, öğretmenlerin teknolojik bilgisinin artması, teknolojik gelişim, eğitim ile teknolojinin daha etkin ve verimli bir şekilde kullanılması, dijital ve teknoloji çağına ayak uydurulması, öğretmenlerin teknoloji kullanımının artması, öğrencilerin küçük yaşta uzaktan eğitim teknolojisini tanımış olmaları, idarecilerin teknoloji bilgisinin artması, teknolojinin eğitim için faydalarının anlaşılması, eğitimin farklı ve alternatif araçlarla yapılması, bazı öğrencilerde öz denetimin artması, velilerin teknoloji bilgisinin artması, öğrencilerin teknoloji bilgisinin artması, eğitim ile teknolojinin iç içe olması, eğitsel 
dijital içeriklerin çoğalması ve paylaşılması, bazı öğrencilerin bireysel çalışma (çalışmalarını kendi düzenleme, plân yapma vs.) alışkanlığı kazanması, öğretmenlerin uzaktan eğitim teknolojisini tanımış olmaları, öğrencilerin kendi başına öğrenmeyi öğrenmesi, derslere katılan öğrenciler de okul bilinci gelişmesi, EBA'nın hiç yoktan iyi olması, öğretmenlerin uzaktan eğitimi öğrenmesi, salgın sonrası süreçte tekrara imkân sağlayacak olması, öğrencilerin eksik yönlerinin görülmesi ve velilerin uzaktan eğitimi öğrenmesi şeklinde olumlu görüş ifade etmişlerdir. Teknoloji ile eğitimin iç içe olmasından kaynaklı olumlu yönler temasında bazı katılımcıların görüşleri şöyledir.

Teknoloji kullanımında artış, uzaktan eğitimi hızl tanıma. Teknolojinin ders ve kazanım için kullanılabilir olduğuna dair bir bilinç gelişmesi ve veli ilgisinde artış. Yüz yüze eğitime yönelik bakış açısındaki farkındalığın artması (Ö173).

Öğretmen ve idareciler olarak teknoloji konusunda kendimizi yenilemek zorunda kaldık (M102).

Sağlık açısından olumlu yönler temasında katılımcılar en çok, uzaktan eğitim sayesinde koronavirüs salgınının yayılımının ve bulaş riskinin azaltıldığını ifade etmiştir. Bu tema altında katılımcılar frekans değerlerine göre çoktan aza doğru sıralamada; uzaktan eğitimin sağlık açısından risk taşımaması ve sağlıklı olması, öğrencileri salgına yakalanmasını engellemesi, hastalıktan koruması ve uzak tutması, öğrencilerin salgından dolayı güvende olması, yakın temasın olmaması ve temaslı ortamdan uzak olması, hastalık yapan virüslerden izole bir yaşam sürmemizi sağlaması, sağlık açısından kaygının azalması, korkusuz ve kaygısız ders işleniyor olması, daha steril ve hijyenik ortamda ders işlenmesi, çocukların velilerin yanında olması, okulların eve sı ğdırılması, okul gibi kalabalık ortamlardan uzak tutması ve vaka sayısının kontrol altına alınabilmesi şeklinde olumlu görüş beyan etmişlerdir. Sağlık açısından olumlu yönler temasında bazı katılımcıların görüşleri şöyledir.

Vaka sayısının kontrol altına alınabilmesi açısından olması gereken bir durumdur. Ayrıca çocukların, velilerinin gözetiminde olması, onların sorumluluğunda olması olumludur. Şartlar değişmediği süre içinde, yüz yüze zorunlu eğitim yapılmamalıdır. Uzaktan eğitim bu zorunluluğu ortadan kaldırdığı için de olumludur (Ö142).

Hastalık yapan virüslerden izole bir yaşam sürmemizi sağhlyor (MY25).

Eğitim, öğretmenler ve dersler açısından olumlu yönler temasında, katılımcılar en çok zor şartlara rağmen eğitimin istikrarlı olmasına ilişkin olumlu görüş ifade etmişlerdir. Bu tema altında katılımcılar frekans değerlerine göre çoktan aza doğru sıralamada; hiç eğitim almamaktansa kısmen de olsa uzaktan eğitim ile belirli kazanımların elde edilmesi, şartlar ne olursa olsun eğitime devam edilebilmesi, öğretmenlerin az da olsa öğrencilerine ulaşabilmesi, öğrencilerin derslerden geri kalmaması ve tamamen kopmaması, öğretmenlerin değerinin fark edilmesi, sözel anlatımlı ve teorik derslerde verimli olması, okulun değerinin fark edilmesi, ailelerin sürece daha aktif katılması, yüz yüze eğitimin değerinin fark edilmesi, verilen ödevlerin, takip edilmesinin daha kolay olması, öğrencilerin velilerine daha fazla sorumluluk yüklemesi, derslerin kolaylaşması, kalabalık sınıflar sorununu ortadan kaldırması, veli ilgisinin artması, uzun vadede eğitim maliyetlerini düşürecek olması ve online eğitimle ilgili ciddi bir bilgi birikimi ve tecrübe oluşması şeklinde olumlu görüş beyan etmişlerdir. Eğitim, öğretmenler ve dersler açısından olumlu yönler temasında bazı katılımcıların görüşleri şöyledir.

Şartlar ne olursa olsun eğitime devam edilebileceğini gösterdi. Her evde TV'nin olması sayesinde EBA TV ile her öğrenci eğitimine kaldiğı yerden devam ediyor (Ö82). 
Uzaktan eğitimin en büyük faydası, öğrencilerin eğitim faaliyetlerinden kopuşunu kısmen de olsa engellemesidir (MY87).

Zaman ve mekân açısından olumlu yönler temasında katılımcılar en çok, uzaktan eğitimin evden daha rahat çalışabilme imkânı sağladığını ifade etmişlerdir. Bu tema altında katılımcılar frekans değerlerine göre çoktan aza doğru sıralamada; her zaman eğitim verilebilmesi, her yerde eğitim verilebilmesi, okula gidişte zaman kaybı olmaması, çok erken saatlerde uyanıp yollara düşmenin olmaması, esnek çalışmaya izin vermesi, zaman tasarrufu sağlaması ve kazandırması, daha kısa zamanda daha kalabalık gruplara eğitim verilebilmesi, öğrencilerin kendilerini daha özgür hissetmesi, öğretmenlerin aileleri daha fazla vakit geçirmesi, saat kısıtlamasının olmaması ve okula gelmede problem yaşayan öğrenciler için iyi bir fırsat olması şeklinde görüş beyan etmişlerdir. Zaman ve mekân açısından olumlu yönler temasında bazı katılımcıların görüşleri şöyledir.

Çok erken saatlerde uyanıp yollara dü̧̈me olayı yok. Daha steril ortamda ders işliyoruz okulda akill tahta yok ancak bilgisayardan uzaktan eğitim ile çeşitli video ve sorular paylaşmaktayım (Ö187).

Daha kısa zamanda daha kalabalık gruplara eğitim verilebilmesi (M69).

Diğer olumlu yönler temasında katılımcılar, uzaktan eğitim sayesinde trafik kazalarının azaldığını ve bu süreçte okul idarelerinin çok özverili çalıştıklarını ifade etmişlerdir. Bununla birlikte bazı katılımcılar salgın nedeniyle uzaktan yürütülen eğitimin olumlu yönünün olmadığını belirtmişlerdir. Diğer olumlu yönler temasında bazı katılımcıların görüşleri şöyledir.

Arkadaşlarımızın ve okul idaresinin çok özverili çalısmaları, canlı derslerle çocukları desteklemeleri (Ö112).

Trafik kazaları azaldı. Çocukların güvenliği sağlandı. Çocuklar ve öğretmenler dijital

dünyamın kolaylaş̧ırdığı yaşamla tamıştı (MY77).

\section{Tartışma, Sonuç ve Öneriler}

EBA altyapısı ve TRT-EBA işbirliğinde hazırlanan ve çoğunlukla video dersler ile yürütülmeye çalışılan uzaktan eğitim süreci, öğrencilerin eğitimlerinin kesintiye uğramaması adına önemli bir fırsat olarak görülmektedir. Bununla birlikte araştırmanın bulgularına göre, zorunlu olarak yürütülen uzaktan eğitimin verimliliğine ilişkin okul yöneticisi ve öğretmenlerin bazı endişeleri vardır.

Araştırmanın bulgularına göre, salgın döneminde yürütülen uzaktan eğitime ilişkin en çok tekrarlanan olumsuz görüş, internet erişimine ve teknolojiye bağlı yaşanan sorunlardır. Birçok öğretmen ve öğrenci uzaktan eğitim için gerekli olan teknolojik cihazlara ve stabil bir internet bağlantısına sahip değildir. İnterneti ve teknolojik cihazları olan öğretmen ve öğrenciler ise yoğunluk nedeniyle EBA'ya bağlanmakta güçlük çekmektedir. Alanyazın araştırmalarında benzer sorunların yaşandığı tespit edilmiştir. Başaran, Doğan, Karaoğlu ve Şahin'in (2020) araştırmalarında bazı öğrenciler ve velileri uzaktan eğitim sürecinde teknik aksaklıklar yaşadıklarını, bazı öğretmenler ise uzaktan eğitim sürecinde kullanılan platformların alt yapı eksiklerinin giderilmesini gerektiğini ifade etmişlerdir. Doğan ve Koçak'ın (2020) araştırmasında uzaktan eğitim veren öğretmenlerin $\% 45^{\prime} i$, EBA platformunun alt yapı eksikleri olduğunu ve teknik aksaklıklar yaşadıklarını ifade etmişlerdir.

Uzaktan eğitim için kullanılan platformun istikrarlı bir şekilde çalışıp çalışmaması, öğretmenlerin ve öğrencilerin uzaktan eğitime bakışını olumlu veya 
olumsuz olarak etkilemektedir (Al Lily vd., 2020; Chen, Peng, Yin, Rong, Yang ve Cong, 2020; Jowsey, Foster, Cooper-Ioelu ve Jacobs, 2020; Nenko ve diğ., 2020). Uzaktan eğitimin verimli olarak yürütülebilmesi için eğitim öğretim sürecinde yaşanabilecek teknik sorunlarla ilgilenen ve bu sorunları giderebilecek bir ekibin oluşturulması gerekmektedir (Salleh, Ghazali, İsmail, Alias ve Rahim, 2020).

Araştırmanın bulgularına göre, uzaktan eğitimde özellikle uygulama gerektiren derslerin verimsiz geçmesi ilkokul birinci sınıf öğrencileri ve okumaya yeni geçen öğrencilerin uzaktan eğitime hazır olmaması, örgün eğitim müfredatının uzaktan eğitimle yürütülmeye çalışılması, uzaktan eğitim ders içeriklerinin yetersiz olması, öğretmenlerin öğrencileriyle göz teması kuramaması, derslere devam zorunluluğu olmadığ1 için katılımın düşük olması, öğrencilerden dönüt alınamaması, öğretmenlerin ve öğrencilerin ev ortamlarının uzaktan eğitime müsait olmaması, bazı velilerin canlı derslere müdahil olmaları uzaktan eğitime bakışı olumsuz etkilemektedir. Diğer yandan bu durum eğitimde fırsat ve olanak eşitsizliğini de derinleştirmektedir.

Alanyazında araştırmanın bulgularına benzer sonuçları olan araştırmalar yer almaktadır. Akyürek'e (2020) göre, uzaktan eğitimin birey ve toplum açısından birçok faydaları olmasına rağmen bazı sınırlılıkları vardır. Uzaktan eğitimde örgün eğitimdeki gibi iletişim ve etkileşim sağlanamamakta, öğrencilerin sosyalleşme düzeyi azalmaktadır. Bireysel çalışma alışkanlığı kazanamamış öğrencilerin başarı düzeyi düşebilir. Uzaktan eğitim sürecinde uygulama gerektiren derslerden verim alınamamaktadır. Nenko ve diğerlerinin (2020) araştırmasında, salgın süresince yürütülen uzaktan eğitime ilişkin üniversite öğrencilerinin \%30'u akademisyenlerin uzaktan öğretime hazır olmadıklarını ifade etmiştir. Bazı gelenekçi akademisyenlerin bilişim teknolojilerini kullanma konusunda isteksiz olması uzaktan eğitim sürecini olumsuz etkilemektedir. Chen ve diğerlerinin (2020) araştırmasında benzer şekilde, koronavirüs salgını süresince ilkokul, ortaokul, lise düzeyinde eğitim veren öğretmenlerin, üniversite ve lisans üstü düzeylerinde online eğitim veren akademisyenlerin bilişim teknolojilerini kullanma becerisinin yeterli olmadığı tespit edilmiştir. Online eğitim programının ve derslerin nasıl hazırlanacağını, hangi öğretim platformunu kullanacağını, online eğitim programının nasıl değerlendirileceğini bilmeyen öğretmenlerin varlığı öğrencilerin uzaktan eğitime bakışını olumsuz etkilemiştir.

Bilişim Teknolojileri (BT) öğretmenleri salgın sürecinde diğer branşlardaki öğretmenlere rehberlik yapmakta ve teknik destek sağlamaktadır. BT rehber öğretmenlerinin, öğretmen ve öğrencilerin EBA şifresi almasına rehberlik etmek, öğrencilerin EBA üzerinden yaptıkları paylaşımları kontrol edip uygunsuz paylaşımların kaldırılmasını sağlamak, bu öğrencilere uyarıda bulunmak, okuldaki akıllı tahtalar ve bilişim teknolojileri ile ilgili diğer donanımlarının stabil çalışması için bakım yapmak gibi birçok görevi bulunmaktadır. BT öğretmenleri istemeleri halinde valilik tarafından altı aylık süreler için BT rehber öğretmeni olarak görevlendirilmektedir. Bununla birlikte her okul bir BT rehber öğretmenine sahip değildir (MEB, 2020). BT rehber öğretmeni olmayan okullar uzaktan eğitim sürecinde ihtiyaç duydukları rehberlik ve teknik desteği alamamaktadır.

Uzaktan eğitimde öğretmen öğrenci iletişimin yetersiz olması ve öğretmenlerin bu süreçte yeteri kadar rehberlik yapamaması öğrencilerin derslere 
ilişkin motivasyonunu olumsuz etkilemektedir (Karatepe, Küçükgençay ve Peker, 2020; Keskin ve Özer Kaya, 2020). Örgün eğitimde nitelikli bir eğitim becerisine sahip olmayan öğretmenlerin, online canlı derslerde ne kadar verimli olabileceği tartışmaya açık bir konudur (Han ve Demirbilek, 2020; Karadağ ve Yücel, 2020). Bilişim teknolojileri rehber öğretmeni ve okul EBA temsilcisi olarak görev yapan araştırmacının Han (2020) gözlemlerine göre, uzaktan eğitim programlarını kullanma konusunda isteksiz olan ve yeterli beceriye sahip olmayan öğretmenler sınıf yönetiminde sorunlar yaşamaktadır. Online eğitimde karşılaşılabilecek problemleri öngöremeyen ve siber güvenlik önlemlerinden habersiz olan öğretmenler öğrencileri kontrol etmekte zorlanmaktadır.

Uzaktan eğitim, yaşam boyu eğitim, eğitimde fırsat eşitliği gibi birçok konuda olumlu katkılar sağlayabilecek iken salgın sürecinde birçok eşitsizliğe neden oluştur. Sosyo-ekonomik olarak geri kalmış bölgelerde, öğrenciler bilgiye erişim anlamında dezavantajlı durumdadır. Bu eşitsizlik dijital bölünme olarak adlandırılabilir (Bozkurt, 2020; Karakuş vd., 2020). MEB 'in (2020) “Küresel Salgın Döneminde Uzaktan Eğitim" adlı izleme ve değerlendirme raporunda, öğrencilerin $\% 1,5$ 'nin televizyon veya internet erişimi olmadı̆̆ 1 için EBA ders anlatımlarını izleyemedikleri ifade edilmiştir. Aynı raporda öğrencilerin \%7'sinin internet erişimine sahip olmadığı için online derslere katılamadığı belirtilmiştir. Araştırmanın bulgularında özellikle kırsal bölgelerde internet erişimi olmayan, ekonomik olarak dezavantajlı bölgelerde internet hattı alamayan, senkron dersler için internet kotası yeterli olmayan birçok öğrencinin uzaktan eğitime katılamadığı tespit edilmiştir. Evdeki çalışma ortamı uygun olmayan, sahip olunan bir bilgisayarı veya akıllı telefonu kardeşleriyle paylaşmak durumunda olan öğrenciler, kardeşleriyle ders saatlerinin çakışması nedeniyle uzaktan eğitim derslerine katilamamaktadir.

Uzaktan eğitim sürecinde öğrencilerin memnuniyetini etkileyen en önemli faktör, uzaktan eğitim platformun sorunsuz olarak çalışmasıdır (Chen vd., 2020; Jowsey vd., 2020; Nenko vd., 2020). Araştırmanın bulguları bu veriyi desteklemektedir. Araştırmanın bulgularında, EBA'nın yoğunluktan dolayı yavaş olduğu, bazı zamanlarda EBA'ya giriş yapılamadığı, kullanıcı adı ve şifreleriyle EBA platformuna giren öğrencilerin teknik aksaklıklar nedeniyle sistemden atıldı̆̆ 1 tespit edilmiştir. Bu durum öğretmen uzaktan eğitime bakış açısını olumsuz etkilemektedir. Al Lily ve diğerlerinin (2020) araştırmasında, uzaktan eğitim platformunun sağlıklı bir şekilde çalışmamasının, canlı derslere bağlanamama, ders sırasında bağlantının kopması vb. durumların öğrenci velilerin de uzaktan eğitime bakışını olumsuz etkilediğini göstermektedir.

Sürekli ekran başında olmak ve uzun sürelerde elektronik cihazları kullanmak öğrencilerde bazı fiziksel ve psikolojik rahatsılıklara neden olmaktadır (Al Lily vd., 2020). Salgın nedeniyle çoğunlukla evlerinde bulunan öğrenciler, bu süreçte telefon, tablet ve bilgisayar başında daha fazla vakit geçirmektedir. Bununla birlikte Temel Eğitim Genel Müdürlüğünün 43769797-10.07.01-E.14430520 say1lı ve 08.10.2020 tarihli yazısıyla, ilkokul öğrencilerinin tamamı, ortaokullarda ise sadece sekizinci sınıf öğrencileri haftanın iki günü örgün olarak eğitim alacaktır. Örgün olarak yürütülemeyen diğer derslerin ve diğer kademelerdeki öğrencilerin derslerinin tamamının uzaktan eğitim imkanları kullanılarak yürütülmesi gerektiği 
yazısı tüm devlet okullarına gönderilmiştir. Bu talimat doğrultusunda örgün eğitime katılamayan ve derslerinden geri kalmak istemeyen öğrenciler günlük yedi ders saatini ekran başında geçirmek zorunda kalmaktadır. Bu durumun ne kadar pedagojik ve sağlıklı olduğu tartışmaya açıktır.

Araştırmanın bulgularına göre, uzaktan eğitim sürecinde yaşanan birçok olumsuzlukla beraber, zorunlu uzaktan eğitimin en önemli olumlu yönlerinden biri, virüs bulaşma riskini azaltarak salgının önlenmesine katkı sağlamasıdır. Okul yöneticileri ve öğretmenlere göre, bu süreçte öğrenciler okul gibi kalabalık bir ortama girmek zorunda kalmayarak, ailelerinin yanında daha hijyenik bir ortamda, güven içerisinde eğitimlerine devam edebilmiştir. Alanyazın çalışmaları geçmişte yaşanan salgınlarda benzer önlemlerin alındığını bu dönemlerde uzaktan eğitim yapıldığını göstermektedir (Park vd., 2016). Örneğin H1N1 ve MERS virüslerinin etkili olduğu bölgelerde okullar geçici süreliğine kapatılarak salgının yayılımı azaltılmıştır (Kawana ve Kakehashi, 2015; Park, Jang, Choe, Lee, Ahn, Chung ve Han, 2016). Yamamato ve Altun'un (2020) araştırmasında korona virüs salgın döneminde okulların uzaktan eğitime geçmesiyle bulaş hızı azaltılarak korona virüs virüsü taşıyanların tedavileri için zaman kazanıldı ̆̆ ifade edilmiştir.

Araştırmanın bulgularına göre, uzaktan eğitim sayesinde, eğitimde teknolojinin kullanımı yaygınlaşmış, okul yöneticilerinin, öğretmenlerin, velilerin ve öğrencilerin eğitim teknolojilerini kullanma becerisi artmıştır. Teknolojik gelişimle birlikte eğitimde dijitalleşme sağlanmış, salgın süresince ve sonrasında kullanılabilecek sayısız dijital eğitim içeriği oluşturulmuştur. Uzaktan eğitim kalabalık sinıflar sorununu ortadan kaldırarak, eğitimin bireyselleşmesine ve öğrencilerin kendi öğrenme hızında ilerlemesine imkân sağlamıştır. Öğrenciler zaman ve mekân sınırlaması olmaksızın esnek bir şekilde eğitimlerine devam edebilmiştir. Küçük yaşlarda uzaktan eğitimle tanışan öğrenciler bu süreçte bireysel çalışma alışkanlığı kazanmıştır.

Zorunlu uzaktan eğitimle birlikte yoğun bir şekilde üretilmeye çalışılan dijital ders içerikleri öğrencileri memnun etmektedir (George, 2020). Bu süreçte öğrenciler esnek ders çalışma imkanı ile birlikte, herhangi bir yönlendirme olmadan çalışabilmeyi ve öz disiplini kazanmaktadır (Salleh vd., 2020). Araştırmanın bulgularına göre, uzaktan eğitim öğretmen ve öğrencilerin eğitim öğretim sürecinden tamamen kopmamasını sağlamıştır. Bu süreçte örgün eğitimin, okulun ve öğretmenlerin önemi daha iyi anlaşılmıştır. Bu süreçte birçok aile eğitim öğretim sürecine daha aktif katılmıştır. Bu süreçte okula gitmek için harcanan zaman ve maliyet ortadan kalkmıştır. Bunların dişında uzaktan eğitim sayesinde, okul servislerinin oluşturduğu trafik yoğunluğu ve trafik kazaları da azalmıştır. Bununla birlikte araştırmanın bulgularına göre, yönetici ve öğretmenlerin çoğunluğu salgın sürecinde yürütülen zorunlu uzaktan eğitimin yeteri kadar verimli olmadığını düşünmektedir. Hatta bazı katılımcılar uzaktan eğitimin olumlu bir yönü olmadığını düşünmektedir.

Koronavirüs salgını nedeniyle acil bir şekilde uygulamaya konulan uzaktan eğitim sürecinin iyileştirilmesine ilişkin politika yapıcılara ve araştırmacılara şu önerilerde bulunulabilir.

1- Okul yöneticilerine teknoloji liderliği, e-liderlik gibi konularda uzaktan hizmet içi eğitim verilebilir. 
2- Öğretmenlere yönelik, uzaktan eğitimin etkili, verimli ve güvenli olarak nasıl yürütülebileceğine ilişkin eğitimler düzenlenebilir.

3- TBMM tarafından çıkarılacak bir kanunla, öğretmenlerin ve öğrencilerin uzaktan eğitim için ihtiyacı olan teknolojik cihazları satın alması (KDV muafiyeti vb.) kolaylaştırılabilir.

4- Ulaştırma ve altyapı bakanlığı ile telekomünikasyon şirketleri işbirliğinde, şehir merkezlerinde geniş kapsama alanına sahip, ücretsiz, kablosuz internet hizmeti verilebilir. Köy vb. kırsal alanlarda uydu yoluyla ücretsiz internet hizmeti verilebilir.

5- Araştırmanın benzeri farklı katılımcı gruplarıyla gerçekleştirilebilir. Uzaktan eğitim sürecine ilişkin öğrencilerin ve velilerinin görüşlerini inceleyen araştırmalar yapılabilir.

\section{Kaynakça}

Akyürek, M. (2020). Uzaktan eğitim: Bir alanyazın taraması. Medeniyet Eğitim Araştırmaları Dergisi, 4 (1), 1-9. https:/ / doi.org/10.46423/izujed.709983

Aydemir, M. (2018). Uzaktan eğitim program, ders ve materyal tasarımı. Konya: Eğitim Yayınevi.

Al Lily, A. E.,Ismail, A. F., Abunasser, F. M. and Alqahtani, R. H. A. (2020). Distance education as a response to pandemics: Coronavirus and Arab $\begin{array}{lll}\text { culture. Technology in Society, } & 101317 .\end{array}$ https://doi.org/10.1016/j.techsoc.2020.101317

Başaran, M., Doğan, E., Karaoğlu, E. ve Şahin, E. (2020). Koronavirüs (Covid-19) pandemi sürecinin getirisi olan uzaktan eğitimin etkililiği üzerine bir çalışma. Academia Eğitim Araştırmaları Dergisi, 5(2), 368-397.

Bozkurt, A. (2020). Koronavirüs (Covid-19) pandemi süreci ve pandemi sonrasi dünyada eğitime yönelik değerlendirmeler: Yeni normal ve yeni eğitim paradigmas1. AUAd, 6(3), 112-142. ttps://doi.org/10.29065/usakead.777652

Büyüköztürk, Ş. Çakmak, E. K., Akgün, Ö. E., Karadeniz, Ş. ve Demirel, F. (2010). Bilimsel araştırma yöntemleri. Pegem Akademi.

Cabı, E. ve Ersoy, H. (2017). Yükseköğretimde uzaktan eğitim uygulamalarının incelenmesi: Türkiye örneği. Journal of Higher EducationEScience/Yüksekögretim ve Bilim Dergisi, 7(3). doi: 10.5961/jhes.2017.219

Chen, T.,Peng, L., Yin, X., Rong, J., Yang, J. and Cong, G. (2020, September). Analysis of user satisfaction with online education platforms in China during the Covid-19 pandemic. In Healthcare (Vol. 8, No. 3, p. 200). Multidisciplinary Digital Publishing Institute. doi: 10.3390/healthcare8030200

Cohen, L., Manion, L. and Morrison, K. (2007). Research methods in education (6th ed.). New York, NY: Routledge. https:/ / doi.org/10.4324/9780203029053

Creswel, J. W. (2016). Nitel araştırma yöntemleri: Beş yaklaşıma göre nitel araştırma ve araştırma deseni. (Çev: M. Bütün ve S. B. Demir). Ankara: Siyasal Kitabevi.

Djalilova, K. M. (2020). Advantages and disadvantages of distance learning. Hayka и образованиесегодня, (7), 70-72.

Doğan, S. ve Koçak, E. (2020). EBA sistemi bağlamında uzaktan eğitim faaliyetleri üzerine bir inceleme. Ekonomi ve Sosyal Araştırmalar Dergisi, 7(14), 111-124. https:/ / doi.org/10.25306/skad.896420 
George, M. L. (2020). Effectiveteaching and examination strategies for undergraduate learning during Covid-19 school restrictions. Journal of Educational Technology Systems, 49(1), 23-48. https:/ / doi.org/10.1177/0047239520934017

Haber 7 (2020, 28 Nisan). Binlerce öğretmenin kişisel bilgileri çalındı. Erişim:https:/ / www.sozcu.com.tr/2020/egitim/son-dakika-zoom-skandaliboyut-degistirdi-binlerce-ogretmenin-kisisel-bilgileri-calindi-5778896/

Han, F. ve Demirbilek, N. (2020). Üniversite öğrencilerinin Covid-19 salgını süresince yürütülen zorunlu uzaktan eğitime ilişkin görüşleri. Yayınlanmamış makale taslağı. https://doi.org/10.35826/ijoess.2897

İşman, A. (2008). Uzaktan eğitim. Ankara: Pegem Akademi.

Jowsey, T., Foster, G., Cooper-Ioelu, P. and Jacobs, S. (2020). Blended learning via distance in pre-registration nursingeducation: A scoping review. Nurse education in practice, 102775. https:/ / doi.org/10.1016/j.nepr.2020.102775

Kaçan, A , Gelen, İ . (2020). Türkiye' deki uzaktan eğitim programlarına bir bakış. Uluslararası Eğitim Bilim ve Teknoloji Dergisi, 6 (1), 1-21.

Karadağ, E. ve Yücel, C. (2020). Yeni tip Koronavirüs pandemisi döneminde üniversitelerde uzaktan eğitim: Lisans öğrencileri kapsamında bir değerlendirme çalışması. Yükseköğretim Dergisi, 10(2), $\quad$ 181-192. https:/ / doi.org/10.2399/yod.20.730688

Karakuş, N. Ucuzsatar, N. Karacaoğlu, M. Ö. Esendemir, N ve Bayraktar, D. (2020). Türkçe öğretmeni adaylarının uzaktan eğitime yönelik görüşleri. RumeliDE Dil ve Edebiyat Araştırmaları Dergisi, (19), 220-241. DOI: 10.29000/rumelide.752297. https://doi.org/10.29000/rumelide.752297

Karatepe, F., Küçükgençay, N. ve Peker, B. (2020). Öğretmen adayları senkron uzaktan eğitime nasıl bakıyor? Bir anket çalışması. Journal of Social and Humanities Sciences Research, 7(53), 1262-1274. http://dx.doi.org/10.26450/jshsr.1868

Kawano, S., \& Kakehashi, M. (2015). Substantial impact of school closure on the transmission dynamics during the pandemic flu H1N1-2009 in Oita, Japan. PloSone, 10(12), e0144839. https://doi.org/10.1371/journal.pone.0144839

Keskin, M. ve Özer Kaya, D. (2020). Covid-19 sürecinde öğrencilerin web tabanlı uzaktan eğitime yönelik geri bildirimlerinin değerlendirilmesi. İzmir Katip Çelebi Üniversitesi Să̆lık Bilimleri Fakültesi Dergisi, 5(2), 59-67.

Mayring, P., Gümüş, A. ve Durgun, S. M. (2011). Nitel sosyal araştırmaya giriş: Nitel düşünce için bir rehber. Ankara: Bilgesu Yayıncılık.

MEB (2020). Uzaktan Eğitim. "EBA Destek Noktaları" Uzaktan eğitime erişimin önündeki engelleri kaldırıyor. Erişim. http:/ / uzaktanegitim.meb.gov.tr/www/eba-destek-noktalari-uzaktanegitime-erisimin-onundeki-engelleri-kaldiriyor/icerik/63

MEB (2021). EBA destek noktası. Erişim tarihi: 13.04.2021 http:/ / ebadesteknoktasi.meb.gov.tr/

MEB (2020). Yüz yüze ve uzaktan eğitim. 08 Ekim. Say1: 43769797-10.07.01E.14430520. 
MEB (2020). Fatih projesi BT rehberliği görevini yürütecek öğretmenlerin görevleri. Erişim:

https://tekirdag.meb.gov.tr/meb_iys_dosyalar/2017_08/24132400_EK1_BTR _Gorevleri.pdf

MEB (2020). İzleme ve değerlendirme raporu 2020. “Küresel Salgın Döneminde Uzaktan eğitim". Erişim tarihi: 19.01.2021 https:/ / bianet.org/system/uploads/1/files/attachments/000/003/297/origi nal/MEB_rapor.pdf?1613124134

Merriam, S. B. (2013). Nitel araştırma: Desen ve uygulama için bir rehber (3. Baskıdan Çeviri). Turan (Çev. Ed.). Ankara: Nobel Yayın Dağıtım.

Moore, M.G. and Kearsley, G. (2011). Distance education: A systems view of on line learning (what'snew in education) (3rd ed.). Boston, MA: Wadsworth Publishing.

Moore, M. G. and Kearsley, G. (2005). Distance education a systems view. Thomson Wadsworth.

Nenko, Y., Kybalna, N. And Snisarenko, Y. (2020). The COVID-19 Distance learning: Insight from Ukrainian students. Revista Brasileira de Educação do Campo, 5, e8925-e8925. https:/ / doi.org/10.20873/uft.rbec.e8925

Onat Kocabıyık, O. (2015). Olgu bilim ve gömülü kuram: bazı özellikler açısından karşılaştırma. Trakya Üniversitesi Eğitim Fakültesi Dergisi, 6 (1) , 55-66.

Özer, M. (2020). Educational policy actions by the Ministry of National Education in the times of Covid-19 pandemic in Turkey. Kastamonu Eğitim Dergisi, 28 (3), 1124-1129. https:// doi.org/10.24106/kefdergi.722280

Özyürek, A., Begde, Z., Yavuz, N. F. ve Özkan, İ. (2016). Uzaktan eğitim uygulamasının öğrenci bakış açısına göre değerlendirilmesi. Karabük Üniversitesi Sosyal Bilimler Enstitüsü Dergisi, 6(2), 595-605. https:/ / doi.org/10.14230/joiss227

Park, S. W., Jang, H. W., Choe, Y. H., Lee, K. S., Ahn, Y. C., Chung, M. J., ... \& Han, T. (2016). Avoiding student infection during a Middle East respiratory syndrome (MERS) outbreak: A single medical school experience. Korean journal of medical education, 28(2), 209. doi: 10.3946/ kjme.2016.30

Salleh, F. I. M., Ghazali, J. M., Ismail, W. N. H. W., Alias, M. and Rahim, N. S. A. (2020). The impacts of Covid-19 through online learning usage for tertiary education in Malaysia. Journal of Critical Reviews, 7(8), 147-149. http://dx.doi.org/10.31838/jcr.07.08.30

Silverman D. ve Marvasti, A. (2008). Doing qualitative research: A comprehensive guide. ThousandOaks, CA: Sage.

Solak, H, Ütebay, G. ve Yalçın, B. (2020). Uzaktan eğitim öğrencilerinin basılı ve dijital ortamdaki sınav başarılarının karşılaştırılması. Açık eğitim Uygulamaları ve Araştırmaları Dergisi, 6 (1), 41-52.

Sönmez, V., ve Alacapınar, F. G. (2011). Örneklendirilmiş bilimsel araştırma yöntemleri [Exemplified scientific research methods]. Ankara: ANI Yayınc1lık.

Sözcü (2020, 14 Nisan). Yarım milyondan fazla Zoom hesabı çalındı! Erişim:

https:/ / www.haber7.com/teknoloji/haber/2963602-yarim-milyondan-fazla-zoomhesabi-calindi. 
Şenel, T. ve Aslan, O. (2014). Okul öncesi öğretmen adaylarının bilim ve bilim insanı kavramlarına ilişkin metaforik algıları. Mersin Üniversitesi Ĕğitim Fakültesi Dergisi, 10(2).

Türkiye Cumhuriyeti Anayasası.(1982). Madde 42.

Yamamato, T. G. ve Altun, D. (2020). Coronavirüs ve çevrimiçi (online) eğitimin önlenemeyen yükselişi. Üniversite Araştırmaları Dergisi,3(1), 25-34. Doi: 10.26701/uad.711110

Yaman, E., Mermer, E. Ç., ve Mutlugil, S. (2009). İlköğretim okulu öğrencilerinin etik davranışlara ilişkin görüşleri: Nitel bir araştırma. Değerler Eğitimi Dergisi, 7(17), 93-108.

Yıldırım, A., ve Şimşek, H. (2013). Sosyal bilimlerde nitel araştırma yöntemleri.(9. Genişletilmiş Baskı) Ankara: Seçkin Yayınevi.

Singh, V., \& Thurman, A. (2019). How manyways can we define online learning? A systematic literature review of definitions of online learning (19882018). American Journal of Distance Education,33(4), 289-306. https:/ / doi.org/10.1080/08923647.2019.1663082

Wheeler, C. C., Erhart, L. M. and Jehn, M. L. (2010). Effect of school closure on the incidence of influenza amongs chool-age children in Arizona. Public health reports, 125(6), 851-859. https:/ / doi.org/10.1177/003335491012500612

\section{Summary}

\section{Introduction}

Turkey and the world have entered a new era with the coronavirus pandemic. The pandemic, which profoundly affects many areas of our lives, also significantly impacts our formal education. Vacation time with the start of the pandemic was extended in Turkey. However, due to the spread of the pandemic, schools were not opened, and distance education was started. Thanks to distance education, every individual who cannot receive formal education for various reasons can benefit from educational activities without the time and place limits. With its blended education model, distance education can also be used to support formal education (Aydemir, 2018; Cabı \& Ersoy, 2017; Gelen \& Kaçan, 2020; Moore \& Kearsley, 2011; Özyürek, Begde, Yavuz \& Özkan, 2016). However, during the pandemic period, disruptions related to compulsory distance education, which are tried to be carried out with the formal education curriculum without preparation and planning, concerns about the negative effects that may cause students to spend long periods on the computer and screen for online live lessons, cybersecurity concerns, etc. situations cause education stakeholders and society to view distance education negatively (Han \& Demirbilek, 2020; Karadă̆ \& Yücel, 2020).

In this study, the positive and negative aspects of compulsory distance education were tried to be determined by school administrators' and teachers' opinions based on their experiences in the process. At the end of the study, awareness will be raised about the problems arising in the compulsory distance education process, and a contribution will be made to the quality of distance education to be carried out now and in the future. 


\section{Method}

Phenomenological design, one of the qualitative research designs, was used in the study. School administrators and teachers working in Bingöl province constitute the universe of the study. Participants were selected from non-random sampling methods using the appropriate sampling method. There are 87 volunteer participants in the study group. Descriptive and content analysis of research data collected online were done together.

\section{Findings}

Themes formed within the framework of the opinions of school administrators and teachers on the negative aspects of compulsory distance education; Participants who stated that internet access, technological tools and negativities related to technology (1), negativities regarding the teaching of lessons(2), negativities regarding motivation and communication(3), negativities in terms of equal opportunity in education(4), negativities in terms of classroom management(5), negativities due to being compulsory and unplanned(6), causing new problems(7) and no negative aspects(8). It has been evaluated as a total of eight themes.

Themes formed within the framework of the opinions of school administrators and teachers on the positive aspects of compulsory distance education; The positive aspects stemming from the intertwining of technology and education(1), positive aspects in terms of health(2), positive aspects in terms of education, teachers and lessons(3), participants who stated that there are no positive aspects(4), positive aspects in terms of time and space(5), and other positive aspects(6) were evaluated as a total of six themes.

\section{Discussion and Conclusion}

The most repetitive negative opinion regarding distance education conducted during the pandemic period is the problems related to internet access and technology. Many teachers and students do not have the technological devices required for distance education and a stable internet connection. Teachers and students who have internet and technological devices have difficulty in connecting to the Education Information Network (EBA) due to the density. In distance education, especially the courses requiring practice are inefficient, primary school first-year students and students who are new to reading are not ready for distance education, the formal education curriculum is tried to be carried out with distance education, the distance education course content is insufficient, teachers cannot make eye contact with their students, participation in classes is not mandatory, low level of feedback from students, teachers' and students' home environments not suitable for distance education, some parents' involvement in live lessons negatively affect the attitude towards distance education. This situation also increases the inequality of opportunity in education.

Many students who do not have internet access in rural areas, who cannot get internet line in economically disadvantaged regions, and whose internet quota for synchronous lessons are not sufficient, cannot participate in distance education. Students who have to share a computer or a smartphone with their siblings cannot 
attend distance education classes due to the overlap of the class hours with their siblings.

According to the opinions of school administrators and teachers, distance education carried out during the pandemic process has many positive aspects. One of the most important positive aspects of compulsory distance education is that it contributes to the prevention of the pandemic by reducing the risk of virus transmission. In this process, the students did not have to enter a crowded environment such as a school and could continue their education in a more hygienic environment with their families.

Thanks to distance education, the use of technology in education has become widespread, and the ability of school administrators, teachers, parents, and students to use educational technologies has increased. With technological development, digitalization in education has increased, and numerous digital educational content that can be used during and after the pandemic has been created. Distance education has eliminated the problem of crowded classrooms, individualization of education, and enables students to progress at their own learning speed. Students were able to continue their education flexibly without the time and place limitations. Students who met distance education at an early age gained self-control in this process and gained the habit of individual study.

On the other hand, most of the administrators and teachers think that compulsory distance education carried out during the pandemic period is not efficient enough. Some participants even think that distance education has no positive side. However, distance education ensured that teachers and students were not completely detached from the education and training process. The importance of formal education, school, and teachers is better understood. Many families participated more actively in the education and training process. In this process, the time and cost spent on going to school have been eliminated. The following recommendations can be made to policymakers to improve the distance education process, which was implemented suddenly due to the coronavirus (Covid-19) pandemic and became mandatory overtime.

1. In-service training can be provided to school administrators on subjects such as technology leadership and e-leadership.

2. Training on how to conduct distance education effectively, efficiently, and safely can be organized for teachers.

\section{Araştırmanın Etik İzinleri}

Yapılan bu çalışmada "Yükseköğretim Kurumları Bilimsel Araştırma ve Yayın Etiği Yönergesi" kapsamında uyulması belirtilen tüm kurallara uyulmuştur. Yönergenin ikinci bölümü olan “Bilimsel Araştırma ve Yayın Etiğine Aykırı Eylemler” başlığı altında belirtilen eylemlerden hiçbiri gerçekleştirilmemiştir.

Etik kurul izin bilgileri

Etik değerlendirmeyi yapan kurul ad1 $=$ Bingöl Üniversitesi Rektörlüğü

Etik değerlendirme kararının tarihi=13/07/2020

Etik değerlendirme belgesi sayı numarası=E.11824 


\section{Yazar Bilgileri/Authors' Biodata}

Ferhat HAN, Kilis Milli Eğitim Müdürlüğü Ölçme Değerlendirme Merkezinde Bilişim Teknolojileri Öğretmeni olarak görev yapmaktadır. Yazarın uzaktan eğitim, okula yabancılaşma konularında çalışmaları bulunmaktadır.

Ferhat Han is an Information Technologies Teacher at Kilis Directorate of National Education Assessment and Evaluation Center. The author studies distance education and alienation from school.

Nesip DEMİRBİLEK, Bingöl Üniversitesi Genç Meslek Yüksek Okulu, Çocuk Gelişimi Programında doktor öğretim üyesi olarak görev yapmaktadır. Yazarın uzaktan eğitim, okullarda kayırmacılık davranışları üzerine çalışmaları bulunmaktadir.

Nesip Demirbilek is an assistant profesor in the Child Development Program of Bingöl University Junior Vocational School. The author studies distance education and favoritism in schools.

Hasan DEMİRTAŞ, İnönü Üniversitesi Eğitim Fakültesi, Eğitim Yönetimi Ana Bilim Dalında profesör olarak görev yapmaktadır. Yazarın eğitim ve okul yönetimi, sınıf yönetimi, eğitim denetimi, liderlik, eğitim örgütlerinde değişim konularında çalışmaları bulunmaktadır.

Hasan Demirtaş is a professor at Inönü University, Faculty of Education, Department of Educational Administration. The author studies education and school management, classroom management, educational supervision, leadership, and change in educational organizations. 